\title{
Tax Aggressiveness Prediction Method with Neural Network and Logistic Regression
}

\author{
Kautsar Riza Salman \\ STIE Perbanas Surabaya, \\ Indonesia
}

\begin{abstract}
This study aims to examine the predictive power of tax aggressiveness using neural network and logistic regression methods. This research sample is a company whose shares are listed in the Indonesian Sharia Stock Index (ISSI) in the period 2011-2015. A total of 71 public companies in Indonesia were obtained. Data obtained from Indonesia Stock Exchange. The technique of determining the sample was used purposive sampling. The independent variables used are maqashid sharia index, disclosure index of corporate social responsibility, company size, profitability, leverage, inventory intensity, and capital intensity. The analysis technique used is multiple regression, logistic regression, and neural networks. In the initial test, multiple regression method was used. At this initial stage, other independent variables will be known that can predict the level of tax aggressiveness. In the second stage of the test comparing the prediction model of tax aggressiveness that gives a higher level of accuracy between logistic regression analysis and neural network. Based on the results of the analysis and discussion, it can be concluded that the Neural Network method provides a better level of prediction than logistic regression for training data and testing data.
\end{abstract}

Keywords: Level of tax aggressiveness, maqashid sharia index, level of disclosure of social responsibility, company characteristics, logistic regression, neural network

\section{INTRODUCTION}

This research attempts to predict the tax aggressiveness by entering the maqashid sharia index variable and the level of corporate social responsibility disclosure. The prediction model that will be developed is called the Sharia-based Islamic Tax Aggressive Prediction Model and Social Disclosure. In this model, several control variables are also included, such as company size, profitability, leverage, capital intensity, and inventory intensity. Furthermore, this study will find and compare which prediction models are more accurate to predict the level of tax aggressiveness. This study is intended to compare between the classical models represented by logistic regression with the new model represented by the neural network.

Logistic regression analysis can be used to predict tax aggressiveness. In logistic regression, a logistic model is used to explain the relationship between predictors and responses and to group objects into one of two response categories. In its development, logistic regression can also be used for responses in more than two groups, known as polycotomous logistic regression. Logistic regression in some literature is referred to as a classic model.

One classification method developed from the machine learning group is the Neural Network (NN). This model does not require a measurement scale and certain distribution of predictors or inputs in $\mathrm{NN}$ terminology. In general, there are two major groups in NN associated with the presence or absence of responses, namely supervised and unsupervised NN. In the case of this classification analysis, the $\mathrm{NN}$ used is included in the supervised $\mathrm{NN}$ group, because the learning process (function optimization) is supervised by a response (output classification). In some classification literature, this $\mathrm{NN}$ is often referred to as part of the modern classification model.

The novelty offered in this study is on new methods to predict tax aggressiveness using neural networks and logistic regression. There have been no previous studies comparing neural network methods and logistic regression in order to predict tax aggressiveness. Based on the background of the above problems, the formulation of the problem from this study is which method will provide higher predictive power between logistic regression methods and Neural Network (NN)?

\section{OBJECTIVES OF THE STUDY}

The purpose of this study is to compare logistic regression and Neural Network. Both methods are applied using statistical packages that provide facilities for data analysis using SPSS version 20 software. Each data is divided into two groups, namely data for modeling (training) and evaluation (testing) where training and testing comparisons are 2: 2 . Next will be compared the classification accuracy of each classification method.

\section{Logistic Regression}

\section{FRAMEWORK}

Logistic regression is a special form where the dependent variable becomes two parts or groups (binary). Although the formula can be more than two groups. Logistic regression is a regression that is used to find a regression equation if the dependent variable is a scaleshaped variable. Binary logistic regression is used to find a regression equation where the dependent variable is categorical type two choices such as: yes or no, or more than two choices such as: disagree, agree, strongly agree.

Many categorical response variables have only two categorical values. Observations for each subject of the company can be classified as bankrupt (default) or not bankrupt (non default), with the probability value that will occur is calculated with 1 and 0 . The response variables that become observations follow the Bernoulli distribution with binary random variables that have $\mathrm{P}(\mathrm{Y}=1)$.

\section{Neural Network}

Neural Networks (NN) are adaptive statistical models based on an analogy with brain structures. From this NN can learn to estimate the parameters of several 
populations using a small number of examples (one or several) at a time. NN is basically no different from the standard statistical model. NN is used as a statistical tool in various fields, including psychology, statistics, engineering, econometrics, and even physics. $\mathrm{NN}$ is also used as a cognitive process model by neural and cognitive scientists.

Basically, $\mathrm{NN}$ is built from simple units, sometimes called neurons or cells by analogy with real things. These units are connected by a series of weighted connections. Learning is usually done by modification of the weighted connection. Each unit of code corresponds to the features or characteristics of a pattern that we want to analyze or what we want to use as a prediction. These networks usually organize their units into several layers. This first layer is called the input layer, the last is the output layer. Middle layers (if any) are called hidden layers. The information to be analyzed is fed to the first layer neuron and then propagated to the second layer neuron for further processing. The results of this processing are then distributed to the next layer and so on until the last layer. Each unit receives some information from another unit (or from the outside world through several devices) and processes this information, which will be converted into the unit output.

\section{Literature Review}

The study of the influence of the Islamic maqashid index on tax aggressiveness is still relatively rarely investigated. Until now only Salman, Anshori et al. () which examines the effect of the Islamic maqashid index on the level of tax aggressiveness. Salman et al. (2008) found a positive influence on the Islamic maqashid index on the level of tax aggressiveness on public companies listed on the Indonesia Stock Exchange on the Indonesian sharia stock index (ISSI).

The study of the influence of corporate governance characteristics on tax aggressiveness was carried out by Zemzem \& Ftouhi (2013); Hanum \& Zulaikha (2013); Richardson et al. (2013); Kawor et al. (2014); Boussaidi \& Hamed (2015); and Salman, et al. (2018). Their study results show inconsistent results. The study of Boussaidi \& Hamed (2015) and Zemzem \& Ftouhi (2013) obtained empirical evidence regarding the effect of board size in reducing the level of tax aggressiveness. Salman et al. (2018) found the influence of Islamic governance in reducing the level of tax aggressiveness in Islamic public banks in Indonesia. The results of different studies were obtained by Hanum \& Zulaikha (2013) and Khaoula \& Ali (2012) which showed no influence of the size of independent commissioners and audit committees on the level of tax aggressiveness.

Company characteristics are also variables that affect the level of tax aggressiveness. The characteristics of the company are represented by company size, profitability, and leverage. Empirical research examining the effect of firm size on the level of tax aggressiveness was carried out by Noor et al. (2010); Hsieh (2012); Hanum \& Zulaikha (2013); Zemzem \& Ftouhi (2013); Wang et al. (2014); and Salman, et al. (2018). The results of the study prove that the larger the size of the company results in greater levels of tax aggressiveness as well as Hsieh (2012) and Salman et al. (2018). Hsieh (2012) and Salman et al. (2018) found that companies that have a larger size tend to be more able to utilize tax incentives so as to reduce taxable income and income tax payable. Most other researchers like Noor et al. (2010); Hanum \& Zulaikha (2013); Zemzem \& Ftouhi (2013); and Wang et al. (2014) produce different study results, namely the size of the company negatively affects the level of tax aggressiveness. The results of their study explain that companies that have a larger size and in this case indicated by the total value of assets or large sales will result in taxable income and a higher income tax payable.

Empirical research examining the effect of profitability on the level of tax aggressiveness has been carried out by Derashid \& Zhang (2003); Adhikari et al. (2006); Noor et al. (2008); Noor et al. (2010); Hsieh (2012); Zemzem \& Ftouhi (2013); Hanum \& Zulaikha (2013); and Salman et al. (2018). Their study shows contradictory results. Most of their research proves that there is a negative influence of profitability on the effective tax rate (ETR), in other words it shows a positive influence of profitability on the level of tax aggressiveness. In contrast, different results were obtained by Hsieh (2012), Zemzem \& Ftouhi (2013), and Salman et al. (2018). The results of their study found that companies that have a higher level of profitability, have a tendency to lower tax aggressiveness. This is in accordance with the concept of income tax regarding progressive tax rates where companies that have higher taxable income will be charged a higher tax rate as well.

Many researchers have examined the effect of leverage on the level of tax aggressiveness as done by Gupta \& Newberrry (1997); Buijink \& Janssen (2000); Adhikari et al. (2006); Richardson \& Lanis (2007); Noor et al. (2010); Hsieh (2012); Hanum \& Zulaikha (2013); Wang et al. (2014); and Salman et al. (2018). Their study shows different results. Most of the study results show that companies that have high leverage are more likely to do higher tax aggressiveness. Companies that have greater total liabilities can charge higher interest costs in their fiscal correction report. Thus, it will have an impact on the amount of income tax paid by the company to be smaller. Conversely, Hsieh (2012), Hanum \& Zulaikha (2013), and Wang et al. (2014) found the negative influence of leverage on the level of tax aggressiveness. This is because the company is bound by an agreement with the creditor so it is less inclined to do tax aggressiveness.

\section{METHODOLOGY}

\section{Population and Sample}

The population of this study is a company listed on the Indonesia Stock Exchange (IDX). Samples were selected according to certain criteria (with purposive sampling method) from 2011 to 2015 . The data used in this study were taken from the Indonesian Capital Market Directory (ICMD), as well as those listed on idx.co.id. In addition, indicators regarding corporate social responsibility disclosures are obtained from the website 
www.globalreporting.org. Criteria used in sample selection include:

1. Companies that issue financial statements and annual reports in a row for the period 2011 - 2015.

2. Companies that have positive earnings in a row for the period 2011 - 2015 because negative earnings can distort the calculation of the level of tax aggressiveness.

3. Companies that have an Effective Tax Rate (ETR) of less than one in a row in the period 2011 - 2015 because more than one ETR will cause problems in the model estimation.

4. Companies that have adequate data on the disclosure of corporate social responsibility for the period 2011 2015.

\section{Variable Descriptions and Indicators}

The research variable is divided into dependent variables and independent variables. Dependent variable is the level of tax aggressiveness (Y). The independent variables include: maqashid syariah index $\left(\mathrm{X}_{1}\right)$, index of corporate social responsibility disclosure $\left(\mathrm{X}_{2}\right)$, company size $\left(\mathrm{X}_{3}\right)$, profitability $\left(\mathrm{X}_{4}\right)$, leverage $\left(\mathrm{X}_{5}\right)$, capital intensity $\left(\mathrm{X}_{6}\right)$, and inventory intensity $\left(\mathrm{X}_{7}\right)$.

1. The level of tax aggressiveness is the level of how much the company reduces the amount of income tax every year. Tax aggressiveness in this study is proxied by an effective tax rate (ETR). ETR is measured by the tax burden divided by income before tax. Companies that carry out tax aggressiveness are given code 1 and companies that do not carry out tax aggressiveness are given 0 .

2. Maqashid sharia is the goal to be achieved by sharia entities. Maqashid sharia in this study was proxied by the maqashid sharia index. The indicator of the maqashid sharia index in this study uses the indicators proposed by Mohammed et al. (2008), Mohammed \& Taib (2009) and Salman et al. (2018) which divides into three objectives, namely tahdzib al-fard (education for individuals), iqamah al-adl (justice), and maslahah (benefit / welfare).

3. Corporate social responsibility is a business commitment to act ethically, operate legally and contribute to improving the quality of life of employees and their families, local communities and the wider community. In this study, the index of disclosure of corporate social responsibility is used as a guideline indicator from the Global Reporting Initiatives (GRI). GRI consists of economic categories (9 indicators), environment (34 indicators), employment practices and work comfort (16 indicators), human rights (12 indicators), community (11 indicators), and responsibility for products (9 indicators). The scores for each item of disclosure are summed and divided by the total items of disclosure expected for each indicator to obtain the disclosure score per indicator.

4. The characteristics of the company in this study include company size, profitability, leverage, capital intensity, and inventory intensity. Company size is measured by total sales. Profitability is measured by return on assets (ROA). ROA is a comparison of pretax profitability to total assets. Leverage is measured by total liabilities divided by total assets. Capital intensity is measured by fixed assets divided by total assets. Inventory intensity is measured by inventory divided by total assets.

\section{Data Analysis Technique}

In this study, each data is divided into two groups, namely data for modeling (training) and evaluation (testing) where the comparison of training and testing is 2: 2. Further classification will be carried out with logistic regression and Neural Networks. Both methods are applied using SPSS version 20 statistical software which provides facilities for data analysis with both methods. The research period is 2011 - 2015. Data for modeling (training) and evaluation (testing) are divided into 2 (two), namely:

1. Comparison 2: 2 uses the same year data between variables $\mathrm{X}$ and $\mathrm{Y}$. Both of these variables ( $\mathrm{X}$ and $\mathrm{Y}$ ) each use modeling data (training) in 2011 - 2012. The evaluation data uses 2013 - 2014

2. Comparison of 2: 2 uses different year data between variables $\mathrm{X}$ and $\mathrm{Y}$. Variable $\mathrm{X}$ is used to predict variable $\mathrm{Y}$ so that variable $\mathrm{X}$ uses the data of the previous year while variable $Y$ uses data for the following year. Data for modeling (training) on $\mathrm{X}$ variables using 2011 - 2012 while the $\mathrm{Y}$ variable uses data from 2012 - 2013. Data for evaluation (testing) on the $\mathrm{X}$ variable uses data in 2012 - 2013 while the $\mathrm{Y}$ variable uses data 2013-2014.

\section{RESULTS AND DISCUSSION}

\section{Logistic Regression}

Comparison of Data Training and Testing 2: 2 (same year)

The Hosmer and Lemeshow test is used as a goodness of fit test to determine whether the model can be used to interpret the relationship between the level of tax aggressiveness and the seven independent variables. The research hypothesis of the Hosmer and Lemeshow test is

$\mathrm{H}_{0}$ : Fit model (the model is able to explain empirical data)

$\mathrm{H}_{1}$ : The model is not Fit

$\mathrm{H}_{0}$ criteria if the $\mathrm{p}$-value of the Hosmer and Lemeshow test is Chi square distribution of more than 0.05 . The results of the model can be seen that the $p$-value is $0.537>0.05$ as in Table 1 , it can be concluded that the null hypothesis cannot be rejected which means that the model is fit.

Table 1. Hosmer and Lemeshow Test Results

\begin{tabular}{rcc}
\hline Chisquare & Df & Sig. \\
\hline 6.993 & 8 & .537 \\
\hline
\end{tabular}

Summary model using Cox and Snell R Square and Nagelkerke R Square. The model results show that the value of Cox and Snell R Square is 0.207 and Nagelkerke $\mathrm{R}$ Square is 0.280. Variable level of tax aggressiveness can be explained by independent variables in the model of 
$20.7 \%$ (Cox and Snell) and 28\% (Nagelkerke) as in Table

2 , while the rest is explained by factors outside the model.
Table 2. Model Summary

\begin{tabular}{ccc}
\hline-2 Log likelihood & Cox \& Snell R Square & Nagelkerke R Square \\
\hline 156.713 & .207 & .280 \\
\hline
\end{tabular}

Statistical results are presented in Table 3.

Table 3. SPSS Results for Modeling (Training) 2: 2

\begin{tabular}{lllllll}
\hline & B & S.E. & Wald & df & Sig. & Exp(B) \\
\hline IMS & 24.906 & 6.378 & 15.251 & 1 & .000 & 0.956 \\
ICSR & -4.717 & 2.126 & 4.923 & 1 & .027 & .009 \\
SIZE & .830 & .355 & 5.462 & 1 & .019 & 2.293 \\
ROA & -8.136 & 2.884 & 7.956 & 1 & .005 & .000 \\
LEV & -.198 & 1.388 & .020 & 1 & .887 & .820 \\
CAPINT & -.918 & 1.165 & .620 & 1 & .431 & .399 \\
INVINT & 1.065 & 1.718 & .385 & 1 & .535 & 2.902 \\
Constant & -9.541 & 4.087 & 5.450 & 1 & .020 & .000 \\
\hline
\end{tabular}

Based on Table 3, it can be concluded that the variables of IMS, ICSR, SIZE, and ROA significantly influence the level of tax aggressiveness while the other three variables (LEV, CAPINT, and INVINT) are not significant. This can be seen in the Wald value which is greater than the table value or by looking at the significance value of both of which are smaller than 0.05 .

Logistic regression model for data effective tax rate (ETR) with comparison of training and testing 2: 2 is as follows:

$$
\begin{aligned}
& P(y=1 \mid x) \\
& =\frac{1}{1+e-\left(-9,541+24,906 x_{1}-4,717 x_{2}+0,830 x_{3}-8,136 x_{4}-0,198 x_{5}-0,918 x_{6}+1,065 x_{7}\right)}
\end{aligned}
$$

or it can also be made with the following equation:

$$
\begin{aligned}
\ln \left(\frac{\mathrm{p}}{1-\mathrm{p}}\right)= & -9,541+24,906 x_{1}-4,717 x_{2}+0,830 x_{3}-8,136 x_{4}-0,198 x_{5} \\
& -0,918 x_{6}+1,065 x_{7}
\end{aligned}
$$

The accuracy of the classification results in the regression model is shown in Table 4.

Table 4. Data Classification Results with Logistic Regression for Modeling (Training) 2: 2

\begin{tabular}{lccccc}
\hline \multirow{2}{*}{ Observed } & & & \multicolumn{3}{c}{ Predicted } \\
& & .00 & & 1.00 & \\
\hline \multirow{2}{*}{ ETR } & .00 & 37 & 20 & 64.9 \\
Overall Percentage & 1.00 & 22 & 61 & 73.5 \\
\hline
\end{tabular}

Table 4 above shows that the results of data classification for modeling (period 2011 - 2012) with a comparison of 2: 2 training and testing with logistic regression is $70 \%$. From the observation results, 57 companies which were non-defaults were precisely predicted to be 37 companies so that the level of prediction accuracy was $64.9 \%$. On the contrary, from the observation results, 83 companies that defaulted correctly were predicted as many as 61 companies so that the level of accuracy of their predictions was $73.5 \%$.

Furthermore, data classification is carried out for data testing (2013-2014 period) with logistic regression. The results showed that the accuracy of the classification was $75 \%$ as shown in table 5 .

Table 5. Data Classification Results with Data Logistic Regression for Evaluation (Testing) 2: 2

\begin{tabular}{lccccc}
\hline \multirow{2}{*}{ Observed } & & & \multicolumn{3}{c}{ Predicted } \\
& & .00 & 1.00 & \\
\hline \multirow{2}{*}{ ETR } & .00 & 37 & 20 & 64.9 \\
Overall Percentage & 15 & 68 & 81.9 \\
\hline
\end{tabular}

\section{Comparison of Data Training and Testing 2: 2 (different years)}

The analysis was continued for data with comparison of training and testing was 2: 2 for different year periods between variables $\mathrm{X}$ and variable $\mathrm{Y}$. Variable $\mathrm{Y}$ used data for the following year period while variable $\mathrm{X}$ used data from the previous year. From the Hosmer Test it is known that the model used in this study is fit because the 
significance value is 0.946 above 0.05 . The results of the Hosmer test are described in Table 6 below.

Table 6. Hosmer and Lemeshow Test Results

\begin{tabular}{ccc}
\hline Chi-square & Df & Sig. \\
\hline 2.809 & 8 & .946 \\
\hline
\end{tabular}

From the summary model, can be seen in Cox and Snell R Square and Nagelkerke R Square by $22.3 \%$ and $29.8 \%$ variables of tax aggressiveness can be explained by independent variables while the rest is explained by factors outside the model. The results of the summary model are shown in Table 7.

Table 7. Model Summary

\begin{tabular}{ccc}
\hline-2 Log likelihood & Cox \& Snell R Square Nagelkerke R Square \\
\hline $157.731^{\mathrm{a}}$ & .223 & .298 \\
\hline
\end{tabular}

The significance test results in table 8 show that there are several variables, namely IMS, ICSR, SIZE, ROA, and CAPINT which significantly influence the tax aggressiveness. The significance value of these variables is below 0.05 or 0.1 . LEV and INVINT variables have no significant effect on tax aggressiveness.

Table 8. SPSS Results on Data for Modeling (Training) 2: 2

\begin{tabular}{lllllll}
\hline & B & S.E. & Wald & Df & Sig. & Exp(B) \\
\hline IMS & 17.916 & 5.754 & 9.695 & 1 & .002 & 0.603 \\
ICSR & -4.003 & 2.165 & 3.418 & 1 & .064 & .018 \\
SIZE & .840 & .347 & 5.843 & 1 & .016 & 2.315 \\
ROA & -9.814 & 3.064 & 10.257 & 1 & .001 & .000 \\
LEV & -1.000 & 1.517 & .435 & 1 & .510 & .368 \\
CAPINT & -3.783 & 1.209 & 9.786 & 1 & .002 & .023 \\
INVINT & 1.874 & 1.620 & 1.339 & 1 & .247 & 6.514 \\
Constant & -8.271 & 3.961 & 4.361 & 1 & .037 & .000 \\
\hline
\end{tabular}

From Table 8 the logistic regression model can be made as follows:

$$
\begin{aligned}
\ln \left(\frac{\mathrm{p}}{1-\mathrm{p}}\right)= & -8,271+17,916 \mathrm{IMS}-4,003 \mathrm{ICSR}+0,840 \text { SIZE }-9,814 \mathrm{ROA}-1 \mathrm{LEV} \\
& -3,783 \mathrm{CAPINT}+1,874 \mathrm{INVINT}
\end{aligned}
$$

The accuracy of the classification results in the regression model is shown in Table 9.

Table 9.

\begin{tabular}{|c|c|c|c|c|}
\hline \multirow{2}{*}{\multicolumn{2}{|c|}{ Observed }} & \multicolumn{3}{|c|}{ Predicted } \\
\hline & & & & Percentage Correct \\
\hline & & .00 & 1.00 & \\
\hline \multirow{3}{*}{$\begin{array}{l}\text { ETR } \\
\text { Over: }\end{array}$} & .00 & 42 & 22 & 65.6 \\
\hline & 1.00 & 23 & 53 & 69.7 \\
\hline & Overall Percentage & & & 67.9 \\
\hline
\end{tabular}

Data Classification Results with Logistic Regression for Modeling (Training) 2: 2

Table 9 shows that the results of data classification by comparing training and testing data $2: 2$ in different years with logistic regression is $67.9 \%$. From the results of observations as many as 64 companies that were nondefaults were precisely predicted as many as 42 companies so that the level of accuracy of the prediction was $65.6 \%$. On the contrary, from the observation of 76 companies that defaulted, it was precisely predicted that there were 53 companies, so the accuracy of the prediction was $69.7 \%$.

Furthermore, the classification of FD data is carried out for testing data 2: 2 (where the $\mathrm{X}$ variable uses the 2012-2013 period while the $Y$ variable uses the period 2013 - 2014) with logistic regression. The results showed that the accuracy of the classification was $72.1 \%$ as shown in Table 10.

Table 10. Data Classification Results with Logistic Regression for Evaluation (Testing) 2: 2

\begin{tabular}{cccccc}
\hline \multirow{2}{*}{ Observed } & & & \multicolumn{3}{c}{ Predicted } \\
& & .00 & 1.00 & PTR \\
\hline ETR & .00 & 32 & 25 & 56.1 \\
Overall Percentage & 1.00 & 14 & 69 & 83.1 \\
\hline
\end{tabular}

Based on Table 11 it is known that the average level of accuracy of data classification for modeling (training) with Logistic Regression is $68.95 \%$. The average level of data classification accuracy for testing is $73.5 \%$. 
Table 11. Accuracy of Financial Distress Data Classification with Logistic Regression method

\begin{tabular}{cccccc}
\hline $\begin{array}{c}\text { Comparison } \\
\text { Training : Testing }\end{array}$ & The same year & \multicolumn{2}{c}{ Different year } & Average Level of Accuracy & Testing \\
Training & Testing & Training & Testing & & \\
\hline $\begin{array}{c}\text { Classification } \\
\text { Accuracy }\end{array}$ & 70 & 75 & 67,9 & 72,1 & 68,95 \\
\hline
\end{tabular}

Neural Network

Comparison of Data Training and Testing 2: 2 (Same Year)

Output results of the accuracy level of the classification results with Neural Network are shown in Table 12.

Table 12. Classification Results with Neural Network for Modeling (Training) 2: 2

\begin{tabular}{ccccc}
\hline Sample & Observed & \multicolumn{3}{c}{ Predicted } \\
& & .00 & 1.00 & Percent Correct \\
\hline \multirow{3}{*}{ Training } & .00 & 52 & 5 & $91.2 \%$ \\
& 1.00 & 11 & 72 & $86.7 \%$ \\
& Overall Percent & $45.0 \%$ & $55.0 \%$ & $88.6 \%$ \\
\hline
\end{tabular}

Table 12 shows that overall the results of the data classification of Tax Aggressiveness for modeling (period 2011-2012) with a comparison of training and testing 2: 2 with Neural Network that is equal to $88.6 \%$. From the results of observations as many as 57 companies that were non-defaults were precisely predicted as many as 52 companies so that the level of accuracy of the prediction was $91.2 \%$. On the contrary, from the observation results, there were 83 companies that defaulted correctly, predicted as many as 72 companies so that the accuracy of the prediction was $88.6 \%$. As for the testing data for the 20132014 period, the prediction accuracy is 95\% as shown in Table 13.

Table 13. Classification Results with Neural Network for Evaluation (Testing) 2: 2

\begin{tabular}{ccccc}
\hline Sample & Observed & \multicolumn{3}{c}{ Predicted } \\
& & .00 & 1.00 & Percent Correct \\
\hline \multirow{3}{*}{ Testing } & .00 & 54 & 3 & $94.7 \%$ \\
& 1.00 & 4 & 79 & $95.2 \%$ \\
& Overall Percent & $41.4 \%$ & $58.6 \%$ & $95.0 \%$ \\
\hline
\end{tabular}

\section{Comparison of Data Training and Testing 2: 2 (Different Years)}

Output results of the level of accuracy of the results of classification with Neural Network using training data for the period 2011-2012 for the $\mathrm{X}$ and 2012-2013 periods for $\mathrm{Y}$ variables are shown in Table 14.

Table 14. Classification Results with Neural Network for Modeling (Training) 2: 2

\begin{tabular}{ccccc}
\hline Sample & Observed & \multicolumn{3}{c}{ Predicted } \\
& & .00 & 1.00 & Percent Correct \\
\hline \multirow{3}{*}{ Training } & .00 & 38 & 26 & $59.4 \%$ \\
& 1.00 & 5 & 71 & $93.4 \%$ \\
& Overall Percent & $30.7 \%$ & $69.3 \%$ & $77.9 \%$ \\
\hline
\end{tabular}

Based on Table 14, it can be seen that the level of accuracy of the prediction of total observations is $77.9 \%$. From the observations of as many as 64 companies that were non-defaults were precisely predicted to be as many as 38 companies so that the level of accuracy of their predictions was $59.4 \%$. On the contrary, from the results of observation, there were 76 companies that defaulted correctly, predicted as many as 71 companies so that the accuracy of the prediction was $93.9 \%$.

Furthermore, for testing data using the period 20122013 for variables X and 2013 - 2014 for variable Y shows the level of accuracy of the prediction of $80.7 \%$ as shown in Table 15.

Table 15. Classification Results with Neural Network for Evaluation (Testing) 2: 2

\begin{tabular}{lllll}
\hline Sample & Observed & $\begin{array}{l}\text { Predicted } \\
.00\end{array}$ & 1.00 & Percent Correct \\
\hline \multirow{3}{*}{ Testing } & .00 & 36 & 21 & $63.2 \%$ \\
& 1.00 & 6 & 77 & $92.8 \%$ \\
& Overall Percent & $30.0 \%$ & $70.0 \%$ & $80.7 \%$ \\
\hline
\end{tabular}


Table 15 shows that the average level of accuracy for training and testing data ( $3: 2$ and $2: 2$ ) is $91.4 \%$ and $100 \%$.

Tabel 16. Ketepatan Klasifikasi Data Financial Distress dengan Neural Network

\begin{tabular}{ccccccc}
\hline $\begin{array}{c}\text { Comparison } \\
\text { Training: } \\
\text { Testing }\end{array}$ & \multicolumn{2}{c}{ Same year } & \multicolumn{2}{c}{ Different year } & \multicolumn{2}{c}{ Average Level of Accuracy } \\
& Training & Testing & Training & Testing & Training & Testing \\
\hline $\begin{array}{c}\text { Classification } \\
\text { Accuracy }\end{array}$ & 88.6 & 95 & 77.9 & 80.7 & 83.25 & 87.85 \\
\hline
\end{tabular}

On average, it was found that the accuracy of data classification Tax Aggressiveness training and testing with Neural Netwrok was better than Logistic Regression.

\section{CONCLUSIONS}

The tax aggressiveness is part of tax planning applied by the companies in order to minimize or reduce the amount of taxes they are supposed to pay. This tax aggressiveness can be done by either lowering the amount of income or increase the amount of load that taxable income (taxable income) is reduced. Then, ultimately, it can reduce the amount of income tax that must be paid by the companies. Tax aggressiveness is a form of tax that is illegal tax evasion or tax avoidance which do not violate the law by exploiting loopholes in tax regulation. The researchers for more than 20 years have struggled to do empirical studies on the determinants that determine tax aggressiveness and provide different findings. The study does not justify that the entire practice of tax aggressive for it is unlawful as described by Frank et al. (2009). The study refers to previous studies which explain that the smaller the tax burden paid by the company, the more the company does tax aggressiveness in the practice of taxation.

This study found that the average level of accuracy of data classification Tax Aggressiveness for data modeling (training) was $68.95 \%$ for logistic regression and $83.25 \%$ for neural networks. These results indicate that methodically, neural networks are the best classification method for data training. The results also showed that the average level of accuracy of data classification Tax Aggressiveness for evaluation data was $73.5 \%$ for logistic regression and $87.85 \%$ for neural networks. This result shows that by method, neural network is the best classification method for testing data. Both of these findings provide evidence that by method, neural networks provide a better level of predictive accuracy than Logistic Regression.

Future research can expand this research by adding other variables such as Islamic governance in relation to the level of tax aggressiveness. In addition, further research can focus more on Islamic bank entities as objects of research so that the variable level of disclosure of social responsibility and the maqashid sharia index can be adjusted to the conditions in Islamic banking.

\section{LITERATURE CITED}

[1] Adhikari, A., Derashid, C. \& Zhang, H. (2006). Public policy,political connections, and effective tax rates: Longitudinal evidencefrom Malaysia. Journal of Accounting and Public Policy, 25, 574-595.

[2] Boussaidi, Ahmed and Mounira Sidhom Hamed. (2015). The Impact of Governance Mechanisms on Tax Aggressiveness: Empirical Evidence From Tunisian Context. Journal of Asian Business Stategy, 5(1), 1-12.

[3] Buijink, W., \& Janssen, B. (2000). Determinants of the variability of corporate effective tax rates (ETR): Evidence for the Netherlands. MARC Working Paper, University of Maastricht.

[4] Frank, M. M., Lynch, L. J., \& Rego, S. O. (2009). Tax reporting aggressiveness and its relation to aggressive financial reporting. The Accounting Review, 84(2), 467-496.

[5] Gupta, S., dan Newberry, K.(1997). Determinants of the variability in corporate effective tax rates: evidence from longitudinal data. Journal of Accounting and Public Policy,16, 134.

[6] Hanum, H. R., \& Zulaikha (2013). Pengaruh Karakteristik Corporate Governance Terhadap Effective Tax Rate. Diponegoro Journal of Accounting Volume 2 No, 2, 1-10.

[7] Hsieh, Y. C. (2012). New evidence on determinants of corporate effective tax rates. African Journal of Business Management, 6(3), 1177

[8] Kawor, S., \& Kportorgbi, H. K. (2014). Effect of Tax Planning on Firms Market Performance: Evidence from Listed Firms in Ghana. International Journal of Economics and Finance, 6(3).

[9] Khaoula, A. \& Ali, Z. M. (2012). Demographic diversity in the board and corporate tax planning in american firms. Business Management and Strategy, 3(1), 72-86.

[10] Mohammed, M. O., \& Taib, F. Md. (2009). Testing The Performance Measured Based on Maqashid al-Shariah (PMMS) Model on 24 Selected Islamic and Conventional Banks. Malaysia: IIUM.

[11] Mohammed, M. O., Razak, D. A., \& Taib, F. Md. (2008). The Performance Measures of Islamic Banking Based on The Maqashid syariah. International Islamic University Malaysia Journal.

[12] Noor, R. M., Fadzillah, N. S. M. \& Mastuki, N., (2010) Corporate tax planning: a study on corporate effective tax rates of Malaysian listed companies. International Journal of Trade, Economics and Finance, 1(2), 189.

[13] Richardson, G., \& Lanis, R. (2007). Determinants of the variability in corporate effective tax rates and tax reform: Evidence from Australia. Grant Richardson and Roman Lanis. Journal of Accounting and Public Policy, 26(6), 689-704.

[14] Richardson, G., Taylor, G., \& Lanis, R. (2013). The impact of board of director oversight characteristics on corporate tax aggressiveness: An empirical analysis. Journal of Accounting and Public Policy, 32(3), 68-88.

[15] Salman, K. R., M. Anshori, et al. "New Insights Of Shariah Maqashid Index As Determinant Of Tax Aggressiveness Level."

[16] Wang, Y., Campbell, M., \& Johnson, D. (2014). Determinants of Effective Tax Rate of China Publicly Listed Companies. International Management Review, 10(1), 10.

[17] Zemzem, A. \& Ftouhi, K. (2013). The Effects of Board of Directors' Characteristics on Tax Aggressiveness. Research Journal of Finance and Accounting, 4(4), 140-147. 